\title{
Performance evaluation of services quality in higher education institutions using modified SERVQUAL approach with grey analytic hierarchy process (G-AHP) and multilevel grey evaluation
}

\author{
Mohsen Zareinejad ${ }^{a^{*}}$, Mohamad Amin Kaviani ${ }^{\mathrm{b}}$, Mohammad Javad Esfahanic and Fatemeh \\ Takamoli Masoule ${ }^{\mathrm{d}}$
}

${ }^{a}$ Young Researchers and Elite Club, Shiraz Branch, Islamic Azad University, Shiraz, Iran

${ }^{b}$ Department of Industrial engineering, Shiraz Branch, Islamic Azad University, Shiraz, Iran

${ }^{c}$ Researchers and Elite Club, Naragh Branch, Islamic Azad University, Naragh, Iran

${ }^{d}$ Master of training management institute of research and planning

C H R O N I C L E

Article history:

Received October 23,2013

Received in revised format

November 25, 2013

Accepted December 12, 2013

Available online

December 152013

Keywords:

SERVOUAL

Modified SERVQUAL

Quality of services

G-AHP

Multilevel Grey Evaluation

\section{A B S T R A C T}

In today's climate of fierce competition, there is a necessity to pay especial attention on customer demands either in manufacturing or service sector. Managers in service sector are under pressure in terms of environmental factors, they focus on customers' satisfaction and this has led to the continuous improvement in the performance of service organizations. Meanwhile, customers' expectations should be properly understood and measured. There have been various efforts to measure the quality of services using the SERVQUAL model. In this study, we try to investigate the concepts and factors influencing the quality of services according to modified SERVQUAL model and then utilize the proposed model of Grey Analytic Hierarchy Process (G-AHP) and Multilevel Grey Evaluation in order to evaluate the quality of services in the framework of Grey Systems Theory (GST). In order to propose our method, we will conduct a case study of the performance of service quality in higher education institutions of Isfahan-Iran.

(C) 2014 Growing Science Ltd. All rights reserved.

\section{Introduction}

Every day, we receive services in different sectors such as education, insurance, banking, finance, hotels, transportation, restaurants, healthcare, etc. Some of these are introduced to us as services, while some others as products and finally some as a combination of both. Delivering a product to customers can be accomplished in an either tangible or non-tangible approach (Kotler, 2000). However, the service sector has a significant share of employment, which increases on a daily basis and this has led the quality to be of special importance in services sector. Higher growth rates and intense competition for the quality of provided services in both developed and developing countries, has made its measurement and evaluation a major challenge for every organization. Managers of

* Corresponding author

E-mail addresses: mohsen.zareinejad@gmail.com(M. Zareinejad)

(C) 2014 Growing Science Ltd. All rights reserved.

doi: $10.5267 /$ j.ds1.2013.12.002 
service organizations today, try to develop the idea and culture of customer orientation in their respective organizations and provide necessary requirements to achieve organization performance improvement while creating a competitive edge through focusing on customers' needs and satisfying their demands, properly. Products and services have many similarities and the quality of services plays essential role to create a unique name. Thus, measuring and improving the quality of services is a necessity in today's life. Higher education institutions, as one of the service organizations, should try to identify their customers' (i.e. students) needs and expectations and to provide them with high quality services to satisfy them and to keep their loyalty to gain a competitive advantage. Providing a high quality service is a necessity for service organizations and educational institutions, especially the universities.

Students as the recipients of university services are considered as the primary sources to identify the educational behaviors of teachers and staff in their own universities. In today's competitive environment, service organizations' managers have found that in order to improve the performance of their organization, it is necessary to evaluate customer satisfaction of the quality of services provided. Therefore, this study evaluates Isfahan University of Technology and Isfahan University in terms of the above-mentioned subjects using a modified SERVQUAL model. We use these factors to measure and assess the performance of quality of services for the institutions mentioned. Since the services consist of non-tangible and non-homogenous factors, measurement of quality in the services sector is much more difficult compared with the manufacturing sector. Because the evaluation are made by considering the linguistic variables and by an evaluator and we also do not have comprehensive and adequate information at our disposal so we need to introduce the foundations of Grey Systems Theory (GST) to measure the uncertainty of the concepts associated with human mind. GST is one of the methods to study the uncertainty, insufficiency and incompleteness of information. We also require an effective instrument to detect and to prioritize the quality of systematic services, an approach that can develop consensus decision-making. Therefore, we will use the theories proposed by Saaty in the 1970s (Saaty, 1980). The Analytic Hierarchy Process (AHP) has been proposed based on the analysis by the human brain for complex problems. It has a widespread use in decision-making. Ranking according to the values obtained by parameters that can be calculated in order to estimate the priority using paired comparisons is an example of this instrument's capabilities (Liu \& Hai, 2005).

\section{Service quality in higher education institutions}

Paying attention to service quality in higher education began in the 1980s and this interest continued until the early 1990s. This increased attention was due to the necessity of higher education institutions to adapt with financial conditions and customers' pressure to improve service quality (Mostafa, 2006). Since in a competitive market, satisfaction of service is the differentiation factor (Ham \& Hayduk, 2003); therefore, students' satisfaction is considered as a decisive factor for the evaluation of higher education institutions. Quality of service is a multidimensional structure obtained from the difference between the existing and the desirable situation from a customer's point of view. Shank et al. (1995) evaluated the service quality in higher education institutions from the professional (teachers) and customer (students) services point of views (Ham, 2003). One of the broad definitions of service quality is paying attention to satisfying the needs or expectations of a customer (Singh \& Khanduja, 2010). Quality is a series of activities, processes, actions and interactions offered to customers in order to solve their problems. It is a multidimensional concept. Service quality is an abstract structure, which is very difficult to define and to measure. There is no value in a product or service unless it would be consumed by a customer (Buyukozkan, et al., 2011). A product or service is considered high quality when it complies with demands and needs of customers.

\section{Literature review}

Many studies have already been conducted to measure service quality using SERVQUAL. Since the integrated models bring better results; in some of previous studies, SERVQUAL has been integrated 
into other models. Table 1 reviews the previous studies together with their objectives and results in educational fields and other integrated models for service quality assessment, which are associated with the current study.

\section{Table 1}

A review of studies, their objectives and results

\begin{tabular}{|c|c|c|}
\hline Tile of study & Area & Objectives \& results \\
\hline $\begin{array}{l}\text { Perceptions about the quality of websites: A } \\
\text { survey amongst students at Northeastern } \\
\text { University and Erasmus University (Iwaarden } \\
\text { et al., 2004) }\end{array}$ & $\begin{array}{l}\text { Web training } \\
2004\end{array}$ & $\begin{array}{l}\text { A comparison of perceptions amongst students at Northeastern University and } \\
\text { Erasmus University about aspects of service quality of educational websites and } \\
\text { selecting the most important factors affecting web services quality from students' } \\
\text { point of view according to SERVQUAL model. }\end{array}$ \\
\hline $\begin{array}{l}\text { The SERVQUAL as a marketing instrument to } \\
\text { Measure services quality in higher education } \\
\text { institutions,. (Arokiasamy, 2012) }\end{array}$ & $\begin{array}{l}\text { Education } \\
2006\end{array}$ & $\begin{array}{l}\text { Selecting the most important dimensions of service quality using the SERVQUAL } \\
\text { model. Assurance was the most important dimension while tangibles comprised the } \\
\text { least important dimension of service quality. }\end{array}$ \\
\hline $\begin{array}{l}\text { Service quality measurement in the Turkish } \\
\text { higher education system with SERVQUAL } \\
\text { method (Yilmaz et al., 2007) }\end{array}$ & $\begin{array}{l}\text { Education } \\
2007\end{array}$ & $\begin{array}{l}\text { Evaluating the service quality at two different universities and selecting the most } \\
\text { important factor in service quality. Students gave the highest importance to both } \\
\text { empathy and responsiveness dimensions. }\end{array}$ \\
\hline $\begin{array}{l}\text { Service quality in higher education : The role } \\
\text { of student expectations (Voss et al., 2007) }\end{array}$ & $\begin{array}{l}\text { Education } \\
2007\end{array}$ & $\begin{array}{l}\text { The role of students' expectations and teachers' teaching quality and identifying the } \\
\text { most important factors affecting students' satisfaction. }\end{array}$ \\
\hline $\begin{array}{l}\text { Service quality measurement on education } \\
\text { service marketing and relationship between } \\
\text { perceived service quality and students' } \\
\text { satisfaction (Okumuş \& Duygun, 2008) }\end{array}$ & $\begin{array}{l}\text { Education } \\
2008\end{array}$ & $\begin{array}{l}\text { Evaluation of service quality in universities. There is a significant difference between } \\
\text { perceptions and expectations of students. Students' perception and satisfaction are } \\
\text { positively related. }\end{array}$ \\
\hline $\begin{array}{l}\text { Adaptation and application of the } \\
\text { SERVQUAL scale in higher education } \\
\text { (Oliveira \& Ferrera, 2009) }\end{array}$ & $\begin{array}{l}\text { Education } \\
2009\end{array}$ & $\begin{array}{l}\text { Evaluation of service quality in universities and determining the most important } \\
\text { dimensions of improving the quality of service. Prioritizing of the five dimensions of } \\
\text { SERVQUAL model in order of their importance: accountability, empathy, reliability, } \\
\text { assurance and tangibles. }\end{array}$ \\
\hline $\begin{array}{l}\text { Evaluation of the importa } \\
\text { quality factor in PMR bas } \\
\text { Theory (Yongqing \& Jiat }\end{array}$ & $\begin{array}{l}\text { PMR } \\
2009\end{array}$ & $\begin{array}{l}\text { Service quality assessment and selecting the most important factors affecting PMR in } \\
\text { order to improve service quality using Grey degree. }\end{array}$ \\
\hline $\begin{array}{l}\text { Fuzzy application in service quality analysis : } \\
\text { An empirical study (Lin, 2010) }\end{array}$ & $\begin{array}{l}\text { Commerce } \\
2010\end{array}$ & $\begin{array}{l}\text { Measuring service quality in four different stores and determining the most important } \\
\text { factors to rank commercial stores using fuzzy sets and modified SERVQUAL. }\end{array}$ \\
\hline $\begin{array}{l}\text { Evaluation of E-commerce service quality } \\
\text { using the AHP (Yu, 2010) }\end{array}$ & $\begin{array}{l}\text { E- } \\
\text { Commerce } \\
2010\end{array}$ & $\begin{array}{l}\text { Assessing the service quality in e-commerce and determining the most important } \\
\text { factors affecting service quality using Analytic Hierarchy Process. }\end{array}$ \\
\hline $\begin{array}{l}\text { Strategic analysis of healthcare service quality } \\
\text { using AHP methodology (Buyukozkan et al., } \\
\text { 2011) }\end{array}$ & $\begin{array}{l}\text { Healthcare } \\
2011\end{array}$ & $\begin{array}{l}\text { Measuring and evaluation of service quality in } 5 \text { hospital units and their prioritization } \\
\text { based on fuzzy AHP model of service quality. Hospital staff should pay more } \\
\text { attention to each other. Professionalism and reliability dimensions led to the } \\
\text { satisfaction in hospital. }\end{array}$ \\
\hline $\begin{array}{l}\text { Using a modified grey relation method for } \\
\text { improving airline service quality (Liou et al., } \\
\text { 2011) }\end{array}$ & $\begin{array}{l}\text { Airlines } \\
2011\end{array}$ & $\begin{array}{l}\text { Evaluation of service quality and ranking of } 4 \text { airlines in Taiwan using Grey Relation } \\
\text { Theory. }\end{array}$ \\
\hline $\begin{array}{l}\text { Service quality in a Research university: A } \\
\text { post_Graduate perspective(Rajab et al., 2011) }\end{array}$ & $\begin{array}{l}\text { Education } \\
2011\end{array}$ & $\begin{array}{l}\text { Evaluating the satisfaction of English language learners at UTM university after } \\
\text { graduation and performance quality in students at the end of learning period. Creating } \\
\text { the necessary strategies in order to improve the quality before and after the graduation } \\
\text { of English language learners. }\end{array}$ \\
\hline $\begin{array}{l}\text { Influence of service quality, university } \\
\text { image, and student satisfaction Toward WOM } \\
\text { intention : A case study on UPHS university } \\
\text { (Jiewanto et al., 2012) }\end{array}$ & $\begin{array}{l}\text { Education } \\
2012\end{array}$ & $\begin{array}{l}\text { Study of the relationship between service quality, satisfaction and increased } \\
\text { creditability of the university. History of behavioral intentions such as service quality } \\
\text { and customer satisfaction induces an appropriate image of the university through } \\
\text { time. This in turn leads to the promotion of the university and higher service quality. }\end{array}$ \\
\hline $\begin{array}{l}\text { Assessment of quality of education in a non - } \\
\text { government university via SERVQUAL } \\
\text { model (Abari et al., 2011) }\end{array}$ & $\begin{array}{l}\text { Education } \\
2011\end{array}$ & $\begin{array}{l}\text { Service quality measurement in Khourasgan Azad University using the SERVQUAL } \\
\text { model. A significant difference between expectations and perceptions in all five } \\
\text { dimensions of Parasuraman model of service quality. Highest average score belonged } \\
\text { to teachers' perception of their knowledge while lowest average score belonged to } \\
\text { students' perception of their readiness for their future job. }\end{array}$ \\
\hline $\begin{array}{l}\text { A combined fuzzy AHP and fuzzy TOPSIS } \\
\text { based on strategic analysis of electronic } \\
\text { service quality in healthcare industry } \\
\text { (Buyukozkan \& Cifci, 2012) }\end{array}$ & $\begin{array}{l}\text { Healthcare } \\
2012\end{array}$ & $\begin{array}{l}\text { Evaluating the quality of hospital websites using the SERVQUAL model, fuzzy AHP } \\
\text { and fuzzy TOPSIS in order to find the most important dimensions and sub-criteria for } \\
\text { higher customer satisfaction, and improving the service quality through internet } \\
\text { services. Results showed that hospitals should focus more on the allocation of service } \\
\text { accuracy (as a sub-criterion) and, reputation and response (as the main criterion). }\end{array}$ \\
\hline
\end{tabular}

\section{Grey Systems Theory}

In 1982, professor Deng published his first work on the concepts of Grey theory (Deng, 1989). Grey Systems Theory is a very effective technique for solving problems in uncertain conditions with 
discrete data and incomplete information. A system is called a Grey system if part of it includes known data and another part of it includes unknown data. Fuzzy mathematics usually deals with cases where experts express the uncertainty through the membership function. In cases where the number of experts and their level of experience are low, data are insufficient or there are a few instances available and it is not possible to extract the membership function, we can use the Grey Systems Theory (GST). The advantage of Grey System Theory over Fuzzy Theory is that GST includes fuzzy conditions or in other words, GST works well in fuzzy conditions. A Grey set is defined as a set of uncertain data described by Grey numbers, Grey relations, Grey matrices, etc. Grey number of an interval is a set of numbers that their exact amounts are unknown. If $Z$ is a reference set then $X$ Grey sets of $Z$ reference set with two $\mathrm{M}_{\mathrm{x}}(\mathrm{Z})$ symbols as upper and lower limits of a Grey set, are defined by Eq. (1).

$\left\{\begin{array}{l}\underline{M_{X}}(Z): Z \rightarrow[0,1] \\ \underline{M_{X}}(Z): Z \rightarrow[0,1]\end{array} \quad \bar{M}_{\mathrm{X}}(\mathrm{Z}) \geq \underline{M_{\mathrm{X}}}(\mathrm{Z})\right.$

If $\bar{M} \mathrm{X}(\mathrm{Z})=M_{\mathrm{X}}(\mathrm{Z})$, then $\mathrm{X}$ Grey set becomes a fuzzy set that indicates GST inclusion over the fuzzy condition and its flexibility when dealing with fuzzy problems.

\subsection{Grey assessment and ranking}

In order to assess $M$ independent options considering $N$ criteria (dimensions) for ranking in a Grey environment, we should act as the following steps (Lin et al., 2008; Chen et al., 2011).

First step: Preference of option $\pi$ i over the criterion $\pi$ i through Eq. (2).

$\otimes \mathrm{xij}=\frac{1}{k}\left[\otimes x i j+\otimes \mathrm{xij}^{2}+\cdots+\otimes \mathrm{xij}^{\mathrm{k}}\right] \cdot \mathrm{i}=1,2, \ldots, \mathrm{m}, \mathrm{j}=1,2, . ., \mathrm{n}$

where $\otimes x i j^{k}$ is the value of assessment given by the $\mathrm{k}^{\text {th }}$ decision-maker for the $\mathrm{i}^{\text {th }}$ option in terms of the $\mathrm{j}^{\text {th }}$ criterion that could be shown by $\otimes x i j=\left\{\underline{x} i j^{k}, \bar{x} i j^{-k}\right\}$ as a Grey number.

Second step: Creating a Grey decision matrix, where $\otimes x i j$ are linguistic variables, which have been defined based on Grey numbers.

$D=\left[\begin{array}{cccc}\otimes X 11 \otimes \mathrm{X} 12 & \ldots & \otimes \mathrm{X} 1 \mathrm{n} \\ \otimes x 21 & \otimes \mathrm{x} 22 & \ldots . & \otimes \mathrm{x} 2 \mathrm{n} \\ \vdots & \vdots & & \\ \otimes x m 1 \otimes \mathrm{xm} 2 & \ldots . & \otimes \mathrm{xmn}\end{array}\right]$

Third step: Normalization of the decision matrix

$D=\left[\begin{array}{ccc}\otimes X 11^{*} \otimes X 12^{*} & \ldots \otimes X 1 \mathrm{n}^{*} \\ \otimes x 21^{*} \otimes \mathrm{x} 22^{*} & \ldots \otimes \mathrm{x} 2 \mathrm{n}^{*} \\ \vdots & \vdots & \vdots \\ \otimes x m 1^{*} \otimes \mathrm{xm} 2 & \ldots & \otimes \mathrm{xmn}^{*}\end{array}\right]$

1 - If the criteria are positive (the more the better)

$\otimes x i j^{*}=\left[\frac{x i j}{x_{j}^{\max }}, \frac{\overline{x i j}}{x i j^{\max }}\right]$

2- If the criteria are negative (the lower the better) 
$\otimes x i j^{*}=\left[\frac{x i^{\min }}{x i j}, \frac{x j^{\min }}{\underline{x i j}}\right]$

Fourth step: Determining the ideal positive option or the best answer possible as an option in order to be compared with other options. Assume that there $\mathrm{M}$ options defined as $\mathrm{u}=\left\{\mathrm{u}_{1}, \mathrm{u}_{2}, \ldots, \mathrm{u}_{\mathrm{m}}\right\}$. Then the best criteria would be $u^{\max }=\left\{\otimes u_{1}^{\max }, \otimes u_{2}^{\max }, \ldots ., \otimes u_{1 \mathrm{n}}^{\max }\right\}$ that can be calculated using the Eq. (3).

$u^{\max }=\left\{\left[\max \underline{x}_{1 \leq j \leq m}^{*}, \max x i 1_{1 \leq i \leq m}^{*}\right],\left[\max \underline{x i}_{1 \leq i \leq m}^{*} 2, \max i 2_{1 \leq i \leq m}^{*}\right], \ldots\left[\max \underline{x}_{1 \leq i \leq m}^{*} i n, \max \bar{x}_{1 \leq i \leq m}^{*}\right]\right\}$

Fifth step: Using Grey possibility degree to compare each option with $\mathrm{u}^{\max }$ as the desirable option according to Eq. (4) and Eq. (5).

$\mathrm{P}\{\otimes \mathrm{x} \leq \otimes \mathrm{y}\}=\frac{\max \left(0, I^{*}\right)-\max (0, \overline{\mathrm{x}}-\underline{y})}{\mathrm{L}^{*}}$

$\mathrm{L}^{*}=\mathrm{L}(\otimes \mathrm{x})+\mathrm{L}(\otimes \mathrm{y})$

Considering the relationship of $\otimes x, . \otimes y$, four different cases may occur:

1- If $\bar{x}=\bar{y}, \underline{x}-\underline{y}$ then $\otimes \mathrm{x}=\otimes \mathrm{y}$. In that case: $\mathrm{P}\{\otimes \mathrm{x} \leq \otimes \mathrm{y}\}=0.5$

2- If $\underline{y}>\bar{x}$ then $\otimes \mathrm{x}<\otimes \mathrm{y}$. In that case: $\mathrm{P}\{\otimes \mathrm{x} \leq \otimes \mathrm{y}\}=1$

3- If $\overline{\bar{y}}<\underline{x}$ then $\otimes \mathrm{x}>\otimes \mathrm{y}$. In that case: $\mathrm{P}\left\{\otimes \mathrm{x} \leq \otimes_{\mathrm{y}}\right\}=$

If there is interference and $\mathrm{P}\{\otimes x \leq \otimes \mathrm{y}\}>0.5$ then $\otimes \mathrm{x}<\otimes \mathrm{y}$.

If there is interference and $\mathrm{P}\{\otimes x \leq \otimes \mathrm{y}\}<0.5$ then $\otimes x>\otimes \mathrm{y}$.

Therefore, it is possible to make the following comparison between the available options $u=\{$ $u 1, u 2, \ldots u m\}$ and the ideal positive option $\mathrm{u}^{\max }$ :

$$
P\left\{u i \leq u^{\max }\right\}=\frac{1}{n} \sum_{j=1}^{n} p\left\{\otimes \mathrm{x}^{*}{ }_{\mathrm{ij}} \leq u_{j}^{\max }\right.
$$

Sixth step: Ranking of options

The lower the value of $\mathrm{p}\left(u \mathrm{u}<u^{\max }\right)$, the better the rank of option i. Conversely, the closer this value to 1 , the lesser the importance of the respective option.

\subsection{Calculation of the relative Grey score}

In order to calculate the relative Grey score for options in this study, Grey numbers were used on a scale of 7 according to Table 4 .

Step 1: It can be calculated from the following equation for option $\pi \mathrm{i}$ and criterion $\pi \mathrm{j}$.

$\otimes \mathrm{G}_{\mathrm{IJ}=} \frac{1}{K}\left[\otimes G_{i j}^{1}+\otimes G_{i j}^{2} \ldots .+\otimes G_{i j}^{k}\right]$,

where $\otimes G_{i j}^{k}$ is the value of assessment given by the $\mathrm{k}^{\text {th }}$ decision-maker for the $\mathrm{i}^{\text {th }}$ option in terms of the $\mathrm{j}^{\text {th }}$ criterion that could be shown by $\otimes G_{i j}^{k}=\left[\underline{G}_{i j}^{k}, \bar{G}_{i j}^{k}\right]$ as a Grey number.

Step 2: Creating a Grey decision matrix, where $\otimes G_{i j}$ are linguistic variables, which have been defined based on Grey numbers.

Step 3: Normalization of decision matrix that can be calculated based on the type of criteria that are either in form of profit or cost. 
$\mathrm{D}=\left[\begin{array}{cccc}\otimes G_{11} & \otimes G_{12} & \ldots \ldots \otimes G_{1 n} \\ \otimes G_{21} & \otimes G_{22} & \ldots \ldots & \otimes G_{2 n} \\ \vdots & \vdots & & \vdots \\ \otimes G_{m 1} & \otimes G_{m 2} & \ldots & \otimes G_{m n}\end{array}\right]$

A) If the variables are in form of profit (the more the better):

$\otimes G_{i j}^{*}=\left[\frac{G_{i j}}{G_{j}^{\text {max }}}, \frac{\bar{G}_{i j}}{G_{j}^{\text {max }}}\right] \quad G_{j}^{\max }=\max _{1 \leq i \leq m}\left\{\bar{G}_{i j}\right\}$

B) If the variables are in form of cost (the less the better):

$$
\otimes G_{\mathrm{ij}}^{*}=\left[\frac{\mathrm{G}_{\mathrm{j}}^{\mathrm{min}}}{\overline{\mathrm{G}}_{\mathrm{ij}}}, \frac{\mathrm{G}_{\mathrm{j}}^{\mathrm{min}}}{\underline{\mathrm{G}}_{\mathrm{ij}}}\right] \quad G_{j}^{\min }=\min _{1 \leq i \leq m}\left\{\underline{G}_{i j}\right\}
$$

Step 4: Determining the reference or the ideal option based on the type of problem in order to do the assessment.

Step 5: Calculation of the relative Grey coefficient

The relative Grey coefficient between Li and reference options considering the $i^{\text {th }}$ criterion, which is shown with $£_{\mathrm{Oi}(\mathrm{j})}$, is calculated from the following equation:

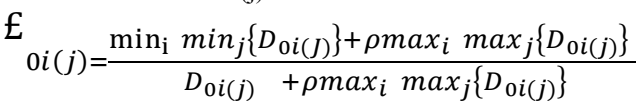

$1 \leq i \leq m \quad 1 \leq j \leq n$

where $D_{O I(J)}$ is the Minkowski distance between the reference options considering the $\mathrm{J}^{\text {th }}$ criterion.

Technical coefficient between the reference options is generally considered according to Wang and $\rho$ is usually 0.5 .

Step 6: Calculation of the relative Grey score

The relative Grey score between $L i$ and reference options is calculated from the following equation: $\gamma_{0 i}=\sum_{j=1}^{n} \frac{1}{n} \quad E_{0 i(j)}$

\section{Grey-AHP}

We recommend using the G-AHP model that is comprised of the Grey system and AHP based on AHP model proposed by Saaty, for this study (Saaty, 1980). This model is proposed for service quality assessment in higher education institutions and finding the best institution in terms of service quality performance. The main steps to use G-AHP are as follows:

1.Goal setting: At this stage, the goal is to assess the service quality in 3 higher education institutions and to find the best institution in terms of service quality performance .

2. Determining the Service quality assessment criteria: At this stage, modified SERVQUAL dimensions and important factors extracted from the SERVQUAL model will be selected as the main and sub-criteria, respectively.

3. Introducing options (alternatives): Higher education institutions under assessment are specified as options or choices.

4. Building the hierarchy of decisions: After determining the selection criteria and options, the hierarchy structure is built based on them. The overall objective will be placed on top of this structure 
and the criteria on lower levels. The available options or choices will then eventually be placed on 3 levels to make decisions. This situation as a general standard framework, regardless of the type of problem, is as described in Fig. 1.

5. Creating the matrix of paired comparisons: This stage includes the paired comparisons and creating the matrix of paired comparisons in each row of the hierarchy in order to answer the realization of objective or to meet its requirements. Each element of this matrix is a Grey number.

Level 1: Goal

Level 2: Criteria

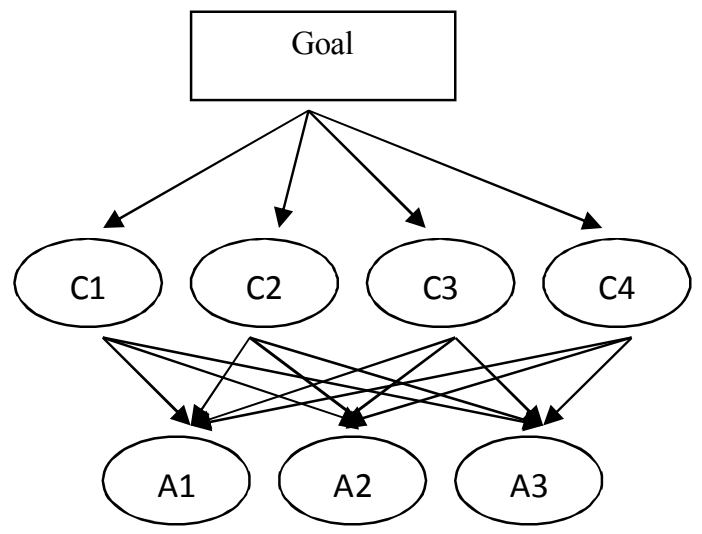

Fig. 1. Hierarchy Structure

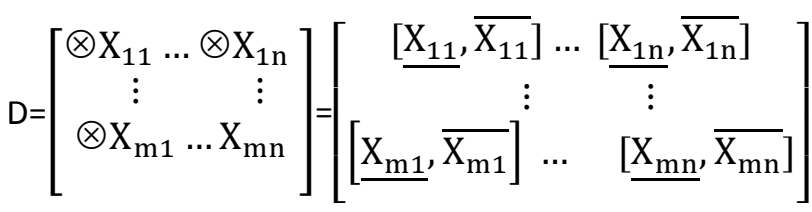

6. Normalization of the paired comparisons matrix:

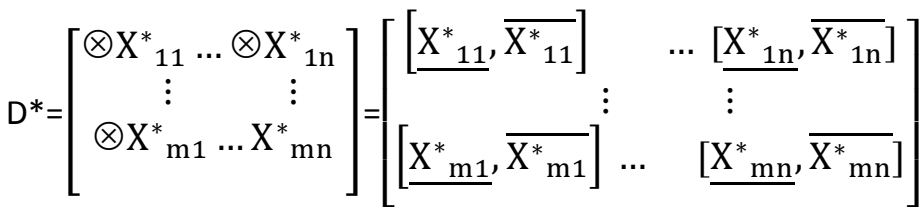

$$
\begin{aligned}
& \underline{x_{i j}^{*}}=\left[\frac{2 x_{i j}}{\sum_{i=1}^{m} x_{i j}+\sum_{i=1}^{m} \overline{x_{i j}}}\right] \\
& \overline{\mathrm{x}^{*}{ }_{\mathrm{ij}}}=\left[\frac{2 \overline{\mathrm{x}_{\mathrm{ij}}}}{\overline{\sum_{\mathrm{i}=1}^{\mathrm{m}} \underline{\mathrm{x}_{\mathrm{ij}}}+\sum_{\mathrm{i}=1}^{\mathrm{m}} \overline{\mathrm{x}_{\mathrm{ij}}}}}\right]
\end{aligned}
$$

7. Calculating the relative weights of criteria and options:

The relative weights of factors in each level are calculated using normalized paired comparisons matrix according to Eq. (10). The calculated weight is a Grey number.

$\mathrm{Wi}=\frac{1}{\mathrm{n}} \sum_{\mathrm{i}=1}^{\mathrm{m}}\left[\underline{\mathrm{x}^{*}{ }_{\mathrm{ij}}}, \overline{\mathrm{x}^{*}}{ }_{\mathrm{ij}}\right]$

8. Calculating the consistency rate $(\mathrm{CR})$ :

After creating the paired comparisons matrix and calculating the relative weights of factors, the consistency of the paired comparisons matrix should be investigated. If the consistency rate of the matrix is lower than 0.1 , then matrix D (decision-maker judgment about the preference of factors 
under comparison) is acceptable, otherwise the contents of matrix D are too inconsistent to give reliable results. In such cases, it is necessary to repeat the paired comparisons by decision-maker until the consistency rate (CR) reaches to the lower than 0.1. CR can be calculated using Eq. (11) to (15).

$$
\begin{aligned}
& \mathrm{WSV}=\mathrm{D} \times W_{i} \\
& \mathrm{Cv}=\mathrm{WSv} \div W_{i} \\
& \lambda \max =\frac{c v}{n} \\
& \mathrm{CI}=\frac{\lambda \max -n}{n} \\
& \mathrm{CR}=\frac{C I}{R I}
\end{aligned}
$$

RI in Eq. (15) is the mean of consistency rate for the random variable. Table 3 shows the value of RI for each value of $\mathrm{n}$ criteria.

9. Calculating the weights of each option (alternative): In order to do this, the vector of relative weights of options should be multiplied by the vector of relative weights of criteria. The calculated numbers in this case are also Grey numbers.

10. Ranking of the options: At this stage, ranking is done based on the final weight of each option. Since final weights are Grey numbers, in order to rank them the vector of positive ideal weight will first be defined according to Eq. (16).

$S^{\max }=\left[\underline{w_{s i}^{\max }}, \overline{w_{s l}^{\max }}\right]$

We then use the Grey possibility degree. If the Grey weight of the $\mathrm{i}^{\text {th }}$ option is $\left[\underline{w_{i}}, \overline{w_{l}}\right]$ and $s_{i}=\left[w_{s i}^{\max }, \overline{w_{s l}^{\max }}\right]$ is the positive ideal option, the Grey possibility degree $\mathrm{p}\left(s^{\max } \leq s_{\mathrm{i}}\right)$ for each option is calculated according to Eq. (4) and the option having the lowest calculated value, will be selected as the best option.

\section{Research methodology}

The standard modified SERVQUAL questionnaire with a Grey rating of seven that consists of 41 questions in five dimensions has been used in this study. The validity of this questionnaire was approved by the professors and experts. After assessing service quality and measuring expectations and perceptions, 16 factors out of 41 were selected as the most important ones based on the opinions of students and provided to 8 experts as paired comparisons in an AHP questionnaire format. This study was carried out at three superior higher education institutions of Isfahan (University of Medical Sciences, University of Technology and University of Isfahan). In order to increase the level of accuracy and making the students' judgments closer to reality in this study, linguistic variables were utilized in SERVQUAL questionnaire and G-AHP questionnaire for paired comparisons using the Grey numbers in Table 3 and Table 4, respectively.

\section{Table 2}

Random numbers

\begin{tabular}{lcccccccccc}
\hline Criteria (n) & 1 & 2 & 3 & 4 & 5 & 6 & 7 & 8 & 9 & 10 \\
\hline RI & 0 & 0 & 0.58 & 0.9 & 1.12 & 1.24 & 1.32 & 1.41 & 1.45 & 1.51 \\
\hline
\end{tabular}


Table 3

Scale for SERVQUAL linguistic variables section

\begin{tabular}{cccccccc}
\hline Scale & Very high & High & Moderately high & Average & Moderately poor & Poor & Very poor \\
\hline $\begin{array}{c}\text { Grey number } \\
\otimes G\end{array}$ & {$[0.9,1]$} & {$[0.7,0.9]$} & {$[0.6,0.7]$} & {$[0.4,0.6]$} & {$[0.3,0.4]$} & {$[0.1,0.3]$} & {$[0,0.1]$} \\
\hline
\end{tabular}

Table 4

Linguistic variables of the paired comparisons matrix in AHP questionnaire

\begin{tabular}{cccc}
\hline Equivalent Grey numbers & Abbreviation symbol & Linguistic variables & Level of importance \\
\hline$[8,10]$ & EMI & Extreme Importance & 9 \\
{$[6,8]$} & VSI & Very Strong Importance & 7 \\
{$[4,6]$} & SI & Strong Importance & 5 \\
{$[2,4]$} & MI & Medium Importance & 3 \\
{$[1,2]$} & EI & Equivalent Importance & 1 \\
\hline
\end{tabular}

\section{Case study}

After identifying the best factors affecting service quality according to students' opinions, hierarchy structure was defined as Fig. 2 in order to identify the best higher education institution in Isfahan based on service quality. The paired comparisons matrices were then created by experts in order to give weight to each factor in its respective level (Table 5).

\section{Options}

Third level: Sub-dimensions (Sub-criteria)

Second level: Dimensions (Criteria)

First level: Objective.

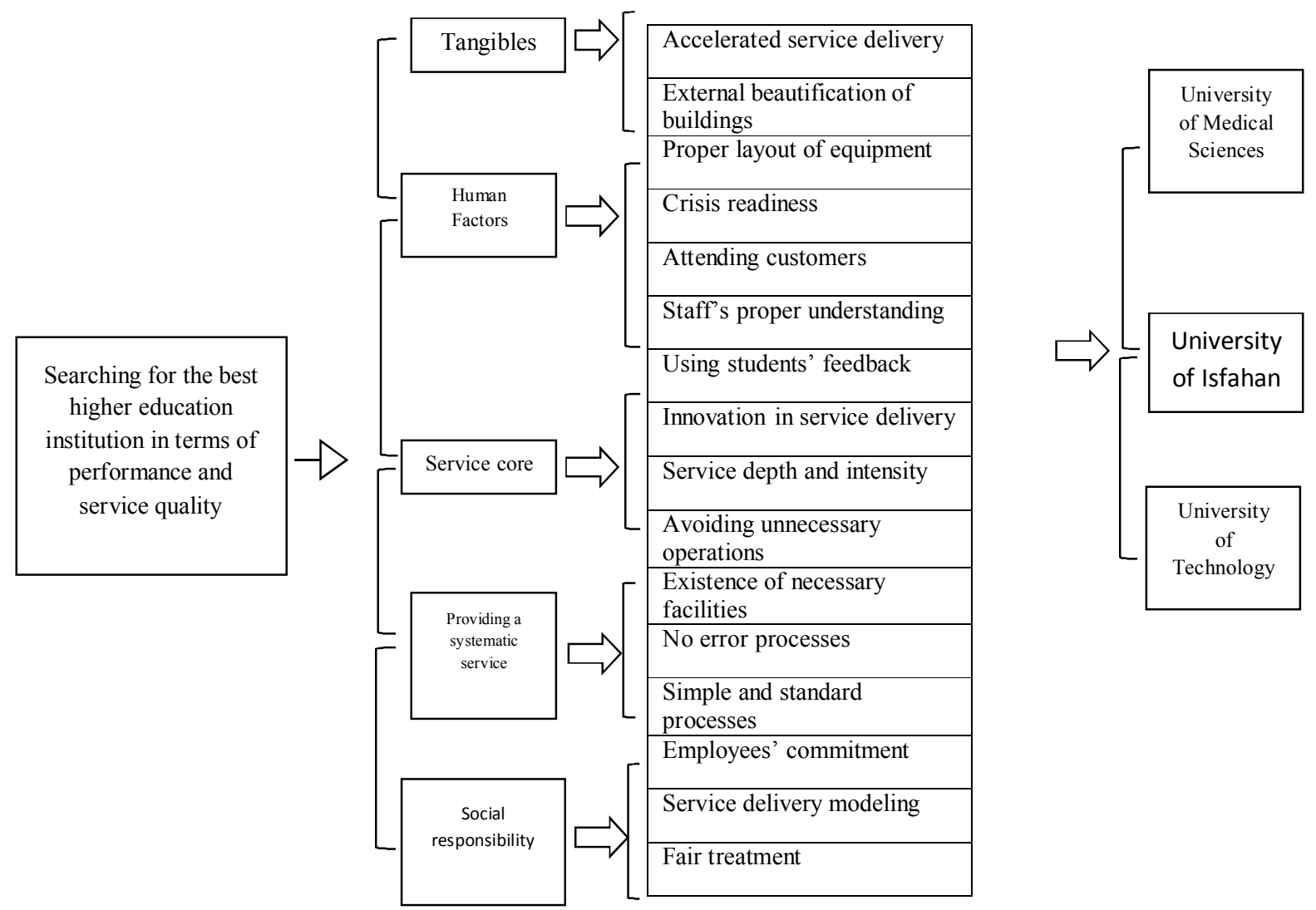

Fig. 2. Hierarchy of service quality assessment based on SERVQUAL model 
Table 5

Matrix of dimensions assessment in terms of objective

\begin{tabular}{llllllllllll}
\hline $\begin{array}{l}\text { Linguistic variable matrix } \\
\text { Objective (C1) }\end{array}$ & C1 & C2 & C3 & C4 & C5 & C1 & C2 & C3 & C4 & C5 & Relative weight $\otimes$ wi \\
\hline Tangibles (C1) & ST & & & & & {$[1,1]$} & {$\left[\frac{1}{6}, \frac{1}{4}\right]$} & {$\left[\frac{1}{6}, \frac{1}{4}\right]$} & {$\left[\frac{1}{6}, \frac{1}{4}\right]$} & {$\left[\frac{1}{8}, \frac{1}{6}\right]$} & {$[0.034,0.45]$} \\
Human factors (C2) & ST & - & & EI & & {$[4,6]$} & {$[1,1]$} & {$\left[\frac{1}{4}, \frac{1}{6}\right]$} & {$[1,2]$} & {$\left[\frac{1}{4}, \frac{1}{2}\right]$} & {$[108,180]$} \\
Service core (C3) & ST & MT & - & MI & & {$[4,6]$} & {$[2,4]$} & {$[1,1]$} & {$[2,4]$} & {$\left[\frac{1}{4}, \frac{1}{2}\right]$} & {$[0.182,0.310]$} \\
Providing a systematic service (C4) & SI & & & & & {$[4,6]$} & {$\left[\frac{1}{2}, 1\right]$} & {$\left[\frac{1}{6}, \frac{1}{4}\right]$} & {$[1,1]$} & {$\left[\frac{1}{6}, \frac{1}{4}\right]$} & {$[0.090,0.134]$} \\
Social responsibility (C5) & EMI & MI & MI & SI & - & {$[6,8]$} & {$[2,4]$} & {$[2,4]$} & {$[4,6]$} & {$[1,1]$} & {$[0.460,0.530]$} \\
\hline Lmax $=5.42 \quad$ CR $=0.94$ & & & & & & & & & & &
\end{tabular}

$\operatorname{Lmax}=5.42 \quad \mathrm{CR}=0.94$

\section{Table 6}

Matrix of sub-dimensions assessment in terms of tangibles

\begin{tabular}{|c|c|c|c|c|c|c|c|}
\hline Linguistic variable matrix & & & & Grey $n$ & er mat & & \\
\hline Tangibles $(\mathrm{C} 1)$ & $\mathrm{C} 11$ & $\mathrm{C} 21$ & $\mathrm{C} 31$ & $\mathrm{C} 11$ & $\mathrm{C} 21$ & $\mathrm{C} 31$ & Relative weight $\otimes \mathrm{w}_{\mathrm{i}}$ \\
\hline Proper layout of equipment (C12) & - & & & {$[1,1]$} & {$\left[\frac{1}{4}, \frac{1}{2}\right]$} & {$\left[\frac{1}{6}, \frac{1}{4}\right]$} & {$[0.69,0.122]$} \\
\hline External beautification of buildings (C21) & MI & - & & {$[2,4]$} & {$[1,1]$} & {$\left[\frac{1}{6}, \frac{1}{4}\right]$} & {$[0.145,0.259]$} \\
\hline Accelerated service delivery (C31) & ST & ST & - & {$[4,6]$} & {$[4,6]$} & {$[1,1]$} & {$[0.592,0.770]$} \\
\hline
\end{tabular}

$\lambda \max =1.3, \quad \mathrm{CR}=0.08$

Relative weight of each option (alternative) is calculated by multiplying the matrix of weight vector for each sub-dimension by weight vectors of university assessment in terms of sub-dimensions.

Table 7

Calculation of relative weight for each alternative

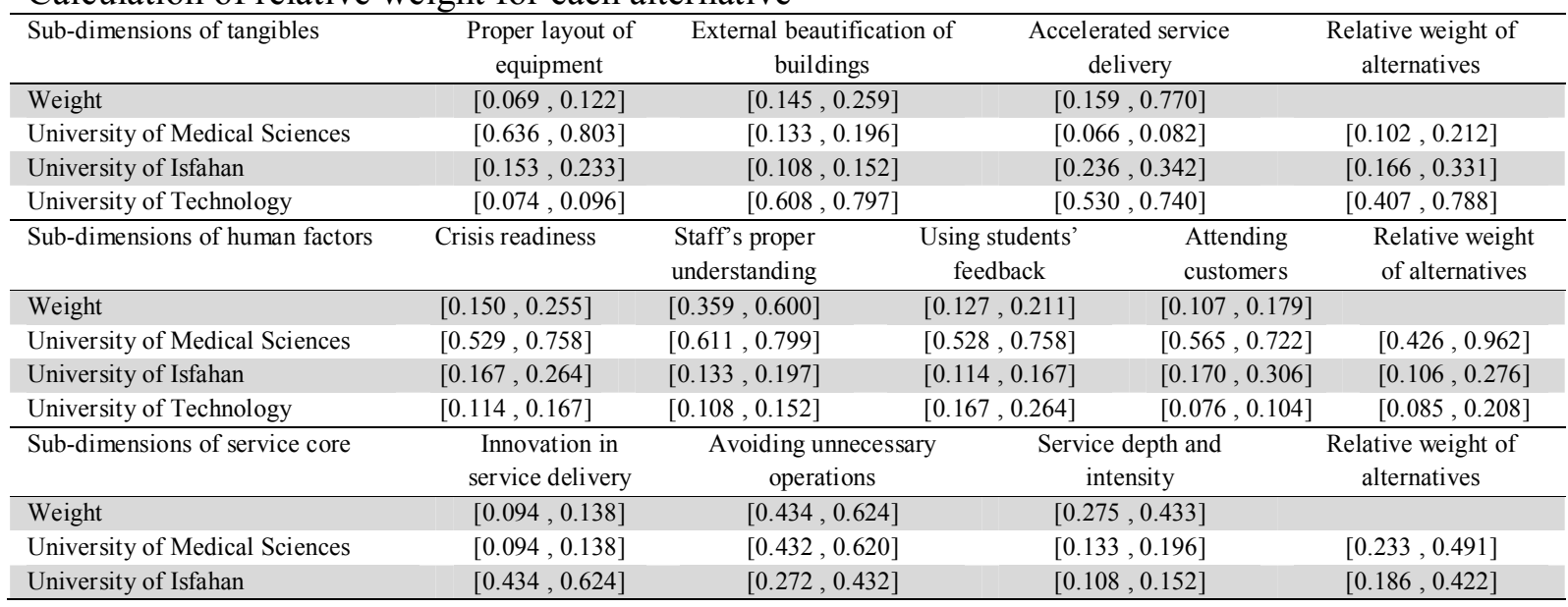

\section{Table 8}

Calculation of relative weight for each alternative- Continued

\begin{tabular}{ccccc}
\hline $\begin{array}{c}\text { Sub-dimensions of providing } \\
\text { a systematic service }\end{array}$ & $\begin{array}{c}\text { No error } \\
\text { processes }\end{array}$ & $\begin{array}{c}\text { Existence of necessary } \\
\text { facilities }\end{array}$ & $\begin{array}{c}\text { Simple and standard } \\
\text { processes }\end{array}$ & $\begin{array}{c}\text { Relative weight of } \\
\text { alternatives }\end{array}$ \\
\hline Weight & {$[0.432,0.620]$} & {$[0.272,0.432]$} & {$[0.094,0.136]$} & \\
University of Medical Sciences & {$[0.114,0.167]$} & {$[0.528,0.758]$} & {$[0.565,0.772]$} & {$[0.246,0.536]$} \\
University of Isfahan & {$[0.167,0.264]$} & {$[0.114,0.167]$} & {$[0.076,0.306]$} & {$[0.120,0.277]$} \\
University of Technology & {$[0.528,0.758]$} & {$[0.167,0.264]$} & {$[0.076,0.104]$} & {$[0.281,0.598]$} \\
\hline
\end{tabular}

\section{Table 9}

Calculation of relative weight for each alternative

\begin{tabular}{lcccc}
\hline $\begin{array}{l}\text { Sub-dimensions of social } \\
\text { responsibility }\end{array}$ & Fair treatment & Employees' commitment & $\begin{array}{c}\text { Service delivery } \\
\text { modeling }\end{array}$ & $\begin{array}{c}\text { Relative weight of } \\
\text { alternatives }\end{array}$ \\
\hline Weight & {$[0.529,0.758]$} & {$[0.167,0.264]$} & {$[0.114,0.167]$} & {$[0.415,0.822]$} \\
University of Medical & {$[0.611,0.799]$} & {$[0.434,0.624]$} & {$[0.170,0.306]$} & \\
Sciences & & & & {$[0.076,0.104]$} \\
University of Isfahan & {$[0.133,0.197]$} & {$[0.094,0.138]$} & {$[0.565,0.772]$} & {$[0.095,0.203]$} \\
University of Technology & {$[0.108,0.152]$} & {$[0.275,0.434]$} & {$[0.167,0.359]$} \\
\hline
\end{tabular}


Table 10

Calculation of relative weight for each alternative

\begin{tabular}{lcccc}
\hline $\begin{array}{l}\text { Sub-dimensions of social } \\
\text { responsibility }\end{array}$ & Fair treatment & Employees' commitment & $\begin{array}{c}\text { Service delivery } \\
\text { modeling }\end{array}$ & $\begin{array}{c}\text { Relative weight of } \\
\text { alternatives }\end{array}$ \\
\hline Weight & {$[0.529,0.758]$} & {$[0.167,0.264]$} & {$[0.114,0.167]$} & \\
$\begin{array}{l}\text { University of Medical } \\
\text { Sciences }\end{array}$ & {$[0.611,0.799]$} & {$[0.434,0.624]$} & {$[0.170,0.306]$} & {$[0.415,0.822]$} \\
University of Isfahan & {$[0.133,0.197]$} & {$[0.094,0.138]$} & {$[0.076,0.104]$} & {$[0.095,0.203]$} \\
University of Technology & {$[0.108,0.152]$} & {$[0.275,0.434]$} & {$[0.565,0.772]$} & {$[0.167,0.359]$} \\
\hline
\end{tabular}

In order to calculate the exponential weight of options, matrix of relative weight for each option (alternative) should be multiplied by the matrix of relative weights of dimensions. Results are shown in Table 11.

\section{Table 11}

Calculation of final weight of performance for each higher education institution based on their service quality

\begin{tabular}{|c|c|c|c|c|c|c|}
\hline Dimensions & Tangibles & Human factors & Service core & $\begin{array}{l}\text { Providing a } \\
\text { systematic service }\end{array}$ & $\begin{array}{l}\text { Social } \\
\text { responsibility }\end{array}$ & $\begin{array}{l}\text { Weight of } \\
\text { alternatives }\end{array}$ \\
\hline Weight & {$[0.034,0.045]$} & {$[0.108,0.180]$} & {$[0.182,0.310]$} & {$[0.090,0.134]$} & {$[0.460,0.530]$} & \\
\hline $\begin{array}{l}\text { University of Medical } \\
\text { Sciences }\end{array}$ & {$[0.102,0.212]$} & {$[0.426,0.962]$} & {$[0.233,0.491]$} & {$[0.242,0.536]$} & {$[0.415,0.822]$} & {$[0.305,0.843]$} \\
\hline $\begin{array}{l}\text { University of Isfahan } \\
\text { University of Technology }\end{array}$ & $\begin{array}{l}{[0.166,0.331]} \\
{[0.407,0.788]}\end{array}$ & $\begin{array}{l}{[0.106,0.276]} \\
{[0.085,0.208]}\end{array}$ & $\begin{array}{l}{[0.186,0.422]} \\
{[0.234,0.491]}\end{array}$ & $\begin{array}{l}{[0.120,0.277]} \\
{[0.281,0.598]}\end{array}$ & $\begin{array}{l}{[0.095,0.203]} \\
{[0.168,0.359]}\end{array}$ & $\begin{array}{l}{[0.106,0.340]} \\
{[0.169,0.496]}\end{array}$ \\
\hline
\end{tabular}

In the last stage, the higher education institutions are ranked based on their service performance using Grey possibility degree (GDP) and considering the ideal weight. The lower the GDP, the better is the respective option. As you can see, $\mathrm{p}\left(\mathrm{U} 1 \leq \mathrm{U}^{\max }\right)=0.5, \mathrm{p}\left(\mathrm{U} 2 \leq \mathrm{U}^{\mathrm{max}}\right)=0.94$ and $\mathrm{p}\left(\mathrm{U} 3 \leq \mathrm{U}^{\max }\right)=0.78$; thus, ranking of the institutions is as follows:

(Rank 1):University of Medical Sciences (U1) > (Rank 2): University of Technology (U2) < (Rank 3): University of Isfahan (U3)

\section{Analysis of data}

After identifying the most important factors using the modified SERVQUAL model in this study, five main dimensions of service and their sub-dimensions were evaluated using G-AHP. Paired comparisons were carried out by experts that had consensus in their judgments using linguistic variables and Grey numbers. As it is shown in Table 6, social responsibility was identified as the most important dimension to assess service quality in higher education institutions according to the Grey possibility degree (GPD). Service core that includes the service principle regardless of the way of its delivery, was placed in second rank considering its lower GDP. Human factors, providing a systematic service and tangibles were finally comprised the next priorities for increasing of satisfaction about the performance of higher education institutions in this study. Sub-dimensions were prioritized for the satisfactory performance of higher education institutions by an overall look at the weights obtained from the paired comparisons tables. The order of priority is: 1- Accelerated service delivery, 2- Fair treatment, 3- Avoiding unnecessary operations, 4- No error processes, 5- Staff's proper understanding, 6- Service depth and intensity, 7- Existence of necessary facilities, 8Employees' commitment, 9- External beautification of buildings, 10- Crisis readiness, 11- Using students' feedback, 12- Attending customers (students), 13- Service delivery modeling, 14Innovation in service delivery, 15- Simple and standard processes and 16- Proper layout of equipment. 
Three superior higher education institution of Isfahan were compared with each other in this study using G-AHP for their service quality performance. Considering all the calculations, the performance ranking of these institutions is as follows:

University of Medical Sciences > University of Technology > University of Isfahan

University of Medical Sciences had the best performance among the other universities in this study. This does not mean that the above-mentioned university provides glamorous services. Other universities should in fact improve their service quality based on these criteria in order to provide services to their students compared to the superior university.

\section{Grey score}

After following the steps listed, Grey score of dimensions was calculated as follows:

Tangibles dimension $=0.5598$, Providing a systematic service dimension $=0.60836$

Social responsibility dimension $=0.7429$ Human factors dimensions $=0.67051$

Above results showed that students gave more importance to social responsibility dimension and less importance to tangibles dimension.

\section{0-Grey assessment method}

Considering the steps mentioned for Grey assessment:

\section{Step1. Grey decisions matrix}

$\left(\begin{array}{l}{[0.1735,0.475][0.0925,0.455][0.089,0.432][0.1271,0.420][0.875,0.415]} \\ {[0.1515,0.493][0.1066,0.4525][0.218,0.562][0.210,0.543][0.1911,0.5326]} \\ {[0.072,0.399][0.3066,0.6591][0.338,0.642][0.468,0.752][0.35,0.648]}\end{array}\right)$

Step2. we use the normalized vector of dimensions weight:

$[0.3815,0.41469,0.46687,0.5064,0.457]$

The normalized weight matrix is as follows:

$\left(\begin{array}{ccccc}{[0.05772,0.158076]} & {[0.086,0.414]} & {[0.096,0.466]} & {[0.1531,0.506]} & {[0.0943,0.457]} \\ {[0.05562,0.181051]} & {[0.846216,0.359227]} & {[0.0737,0.19022]} & {[0.1175,0.30623]} & {[0.07353,0.20491]} \\ {[0.06875,0.381]} & {[0.058084,0.12486]} & {[0.06459,0.1226]} & {[0.0855,0.1373]} & {[0.0604,0.11187]}\end{array}\right)$

Step 3. Grey possibility degree (GPD) values for universities in this study

University of Medical Sciences GPD $=0.5583757$

University of Technology GPD $=0.7179549$

University of Isfahan GPD $=0.8594079$

Ranking of universities: $1^{\text {st }}$ : University of Medical Sciences $2^{\text {nd }}$ : University of Technology $3^{\text {rd }}$ : University of Isfahan 
Results obtained from both Grey assessment and G-AHP were the same, which indicates that both methods confirm each other. In fact, both methods gave the following ranking:

$1^{\text {st }}$ rank: University of Medical Sciences

$2^{\text {nd }}$ rank: University of Technology

$3^{\text {rd }}$ rank: University of Isfahan

\section{Conclusion}

This study was carried out in order to develop a model to understand the service quality and assess the performance of some superior universities using the modified SERVQUAL approach. Thus, the objective was first to calculate the gap score for sub-dimensions of five main dimensions and then identifying the most important of them in order to be provided to experts. This model was used to measure the performance of higher education institutions compared to each other. Results showed that universities should focus more on social responsibility and human factors so their services lead to more students' satisfaction.

\section{References}

Abari, A. A. F., \& Yarmohamadian, M. H. \& Esteki, M. (2011). Assessment Of quality of education in a non - government university via SERVQUAL Model. Procedia social and Behavioral science. $3^{\text {rd }}$ World Conference on Educational Sciences - WCES, 2299 - 2304.

Alves, A., \& Vieira, A. (2006). The SERVQUAL as a marketing instrument to measure services quality in higher education institutions", Marketing research and Techniques, ESCE/IPS, Compus do IPS , Estefanilha 2910. SETUBAL, PORTUGAL.

Büyüközkan, G., Çifçi, G., \& Güleryüz, S. (2011). Strategic analysis of healthcare service quality using fuzzy AHP methodology. Expert Systems with Applications, 38(8), 9407-9424.

Büyüközkan, G., \& Çifçi, G. (2012). A combined fuzzy AHP and fuzzy TOPSIS based strategic analysis of electronic service quality in healthcare industry. Expert Systems with Applications, 39(3), 2341-2354.

Chen, Y. H., Tseng, M. L., \& Lin, R. J. (2011). Evaluating the customer perceptions on in- flight service quality. African Journal of Business management, 5(7), 2854-2864.

Deng, J. L. (1989). Introduction to grey system theory. The Journal of grey system, 1(1), 1-24.

Ham, L., \& Hayduk, S. (2003). Gaining competitive advantages in higher education: analyzing the gap between expectations and perceptions of service quality. International Journal of Value-Based Management, 16(3), 223-242.

Ham, L. C. (2003). Service quality, customer satisfaction, and customer behavioral intentions in higher education. A dissertation for the degree of doctor of business.

Jos, V. I. (2004). Perceptions about the quality of web sites: a survey amongst students at Northeastern University and Erasmus University. Information \& Management, 41(8), 947-959.

Jiewanto, A., Laurans, C., \& Nelloh, L. (2012). Influence of service quality, university image, and student satisfaction towards WOM intention : A case study on University of Peltia Harapan Surabaya, International conference on Asia pacific Business Innovation and Technology management. Procedia Social and Behavioral Science, 40, 16-23.

Kotler, P. (2000). Marketing management: The millennium edition (p. 29). Upper Saddle River, NJ: Prentice-Hall.

Lin, Y. H., Lee, P. C., \& Ting, H. I. (2008). Dynamic multi-attribute decision making model with grey number evaluations. Expert Systems with Applications, 35(4), 1638-1644.

Lin, H. T. (2010). Fuzzy application in service quality analysis: An empirical study. Expert Systems with Applications, 37(1), 517-526.

Liou, J. J., Hsu, C. C., Yeh, W. C., \& Lin, R. H. (2011). Using a modified grey relation method for improving airline service quality. Tourism Management, 32(6), 1381-1388. 
Liu, F. H. F., \& Hai, H. L. (2005). The voting analytic hierarchy process method for selecting supplier. International Journal of Production Economics, 97(3), 308-317.

Mostafa, M. M. (2006). A comparison of SERVQUAL and IP analysis: Measuring and improving service quality in Egyptian private universities. Journal of Marketing for Higher Education, 16(2), 83-104.

Okumufi, A., \& Duygun, A. (2008). Service quality measurement on education service marketing and relationship between perceived service quality and student satisfaction. Anadolu University Journal of Social Science, 8(2), 17-38.

Oliveira, O. J., \& Ferreira, E. C. (2009, May). Adaptation and application of the SERVQUAL scale in higher education. In Proceedings of POMS 20th Annual Conference Orlando, Florida USA.

Rajab, A., Panatik, S. A., Rahman, A., Rahman, H. A., Shaari, R., \& Saat, M. (2011). Service quality in a Research university : A post _ Graduate perspective . International conference on education Psychology (ICEEPSY 2011), Procedia Social Behavioral Science, 29, 1830-1838.

Saaty, T. L. (1980). The analytic hierarchy process: planning, priority setting, resources allocation. $M$ cGraw-Hill.

Saaty, T. L. (2010). Principia Mathematica Decernendi: Mathematical Principles of Decision Making: Generalization of the Analytic Network Process to Neural Firing and Synthesis. Review Publications.

Singh, R. A. J. D. E. E. P., \& Khanduja, D. (2010). SERVQUAL and model of service quality gaps: a framework for determining and prioritizing critical factors from faculty perspective in higher education. International Journal of Engineering Science and Technology. Vol. 2 (7).

Voss, R., Gruber, T., \& Szmigin, I. (2007). Service quality in higher education: The role of student expectations. Journal of Business Research, 60(9), 949-959.

Yilmaz, V., Filiz, Z., \& Yapark, B. (2007). Service quality measurement in the Turkish higher education system with SERVQUAL method.. Anadolu University Journal of Social Science, 7(1), 299-316.

Yongqing, C., \& Jiatao, H. (2009). Evaluating the Importance of Service Quality Factors in PMR Based on Grey Relational Theory. In Information Science and Engineering (ICISE), 2009 1st International Conference on (pp. 4857-4860). IEEE.

$\mathrm{Yu}, \mathrm{Y}$. (2010, January). Evaluation of E-commerce service quality using the analytic hierarchy process. In Innovative Computing \& Communication, 2010 Intl Conf on and Information Technology \& Ocean Engineering, 2010 Asia-Pacific Conf on (CICC-ITOE) (pp. 123-126). IEEE. 